\title{
Solar Electrification in Desert: A Case of Kuwait
}

\author{
Abdullah Al Mutairi, Mohammad Yeakub Ali and Mohd Radzi Che Daud
}

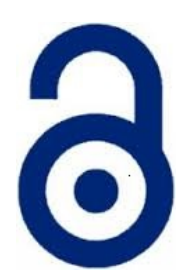

Received: 18 June 2019

Accepted: 11 September 2019

Published: 27 September 2019

Publisher: Deer Hill Publications

(c) 2019 The Author(s)

Creative Commons: CC BY 4.0

\begin{abstract}
Solar energy creates a new lifestyle for mankind, and takes society and human into an era of energy conservation to reduce pollution. It is radiant light and heat from the sun harnessed using a range of ever-evolving technologies such as photovoltaic panel. In this research it is aimed to design and implement PV solar energy home system for electrification in the Kuwaiti dessert during eco-tourism in winter. Eco-tourism is a cultural and unavoidable event in Arab countries with no exception of Kuwait. Eco-tourism is done in remote dessert where urban electricity connections are not possible. As people accustomed in using electrical appliances such as television, room heater, water heater, water pump, they cannot live in the dessert without these amenities. As the weather of Kuwait is sunny and hot during days and cool at night, solar panel based off-grid power cell can be an alternative for electrification of dessert home. This research addressed several critical issues which are appropriate design of PV solar system, estimation of power generation and implementation as solar home system.
\end{abstract}

Keywords: Eco-tourism, Renewable energy, Solar energy, Photovoltaic cell, Off-grid, Shagaya, Kuwait

\section{INTRODUCTION}

Eco-tourism during winter in Kuwait is a cultural and unavoidable event where urban electricity connections are not possible (Mahgoub, 2007). As people accustomed in using electrical appliances such as television, room heater, water heater, water pump, they cannot live in the dessert without these amenities. As the weather of Kuwait is sunny and hot during days and cool at night, solar panel based off-grid power cell can be an alternative. In this case, appropriate design, implementation of solar panel and estimated power generation are critical issues. Solar energy, a kind of renewable energy, has become an important subject of energy research. It is rich in resources, free and no pollution to the environment. Solar energy is radiant light and heat from the sun harnessed using a range of ever-evolving technologies such as photovoltaic panel. Solar energy creates a new lifestyle for humankind, and takes society and human into an era of energy conservation to reduce pollution (Alhouli, 2017).

Eco-tourism during winter in Kuwait is a cultural and unavoidable event. Under this programme people spent time in the dessert especially at night for about 2-3 months. As people accustomed in using electrical appliances such as television, room heater, water heater, water pump, they cannot live in the dessert without these amenities. As there is no electricity supply from national power grid, people use oil fired international combustion engine, power bank charged by direct electricity in urban areas. However, as the weather of Kuwait is sunny and hot during days and cool at night, solar panel based off-grid power cell can be an alternative. In this case appropriate design, implementation of solar panel and estimated power generation are critical issues.

The primary concern of this research is to design an off-grid solar photovoltaic electrification system for Kuwait eco-tourism. Firstly, the feasibility report from this research will have a huge impact for the advancement of solar photovoltaic electrification in Kuwait. Plus, the successful designed photovoltaic system will significantly benefit the homes in the dessert of Kuwait mainly during winter eco-tourism season. Finally, the proposed guidelines and implementation strategy from this research will be useful in producing solar power system for individual house with high efficiency in larger scale for Kuwait. The main scope of this project is to study the weather and identification of

\author{
A. A. Mutairi' M. Y. Ali² ${ }^{2}$ and M. R. C. Daud' \\ 'Department of Manufacturing and Materials Engineering \\ International Islamic University Malaysia \\ PO Box 10, 50728 Kuala Lumpur, Malaysia \\ 2Mechanical Engineering Programme Area, Faculty of Engineering \\ Universiti Teknologi Brunei, Jalan Tungku Link \\ Gadong BE1410, Brunei Darussalam \\ E-mail: yeakub.ali@utb.edu.bn
}

Reference: Mutairi, A. A., Ali, M. Y. and Daud, M. R. C. (2019). Solar Electrification in Dessert: A case of Kuwait. International Journal of Engineering Materials and Manufacture, 4(3), 107-115. 
solar panel parameters to generate solar home system (10-130 Watt peaks) for lighting, television, battery charging, at individual home. The details of the scope include the following:

1. Small houses in desert of Kuwait as the area for the study and investigation for the implementation of the solar photovoltaic system.

2. The design and selection of an off-grid photovoltaic system to generate the required amount of power needed.

3. Assessment and safety and reliability issues in power generation and application for the individual home in the Kuwait dessert.

\section{LITERATURE REVIEW}

In this section, the literatures related to renewable energy especially in the Arabian Gulf countries are discussed. It includes energy crisis and planning, harvesting solar energy and distribution of solar energy in remote and rural areas.

\subsection{RENEWABLE ENERGY PLANNING IN THE GULF COUNTRIES}

The Middle East and North Africa (MENA) has, for most of its modern-day history, been known for its energy wealth. Home to more than half of the world's proven crude oil and more than a third of its natural gas reserves, the dominant story of the MENA region has for the past fifty years been that of a global energy supplier. Consequently, the MENA region's domestic energy market has been seen for decades as marginal in the global picture, supplied with amply available, regionally produced, low-cost fossil fuels. With some of the world's lowest domestic prices for both primary energy and electricity, the MENA region has appeared to lack the kind of economic incentive needed for alternative energy sources, such as renewable energy and nuclear power, to enter its markets (IRENA, 2013). PanArab Renewable Energy Strategy goals are the followings (IRENA, 2014):

1. Utilising the abundance of renewable energy resources;

2. Enhancing future energy security through diversification of energy resources;

3. Meeting the requirements of national and regional development;

4. Keeping indigenous oil and natural gas as strategic reserves for as long as possible; and

5. Contributing to resolving environmental issues associated with oil and gas exploration, transportation and use.

Overall, the Arab region enjoys a rich endowment of renewable energy resources, particularly solar and wind energies. In fact, the region's conditions are very much favourable to produce renewable power system economically. This is more feasible and more attractive than in most other regions of the world (IRENA, 2014). Among all the countries of the world, Kuwait can be said to have one of the greatest demand for electrical power. Its per capita rate of energy consumption is quite high owing to four major factors. First and foremost, Kuwait has a combination of weather conditions that are very extreme. Second, the government of Kuwait offers its citizens high subsidies in so far as electricity is concerned. Third, the general population of Kuwait has been constantly growing over the years and hence, the great demand. Last, the plants available in Kuwait for desalination of water make use of a lot of energy and as such, their energy-intensive status can only allow them to function properly if there is a lot of electricity (Alhouli, 2017). The investment and project on solar energy in GCC are shown in Figure 1 and Figure 2 respectively.

Kuwait witnessed an increase in the demand for electrical power up to two times its normal demand between the years 2003 and 2013. To cater for this demand Kuwait established an energy park of 70 Megawatts to be completed in 2016. In the second and third phases, the country intended to establish projects to generate 930 Megawatts and 1000 Megawatts of electrical energy, respectively. Plans are underway to ensure that solar projects are completed.

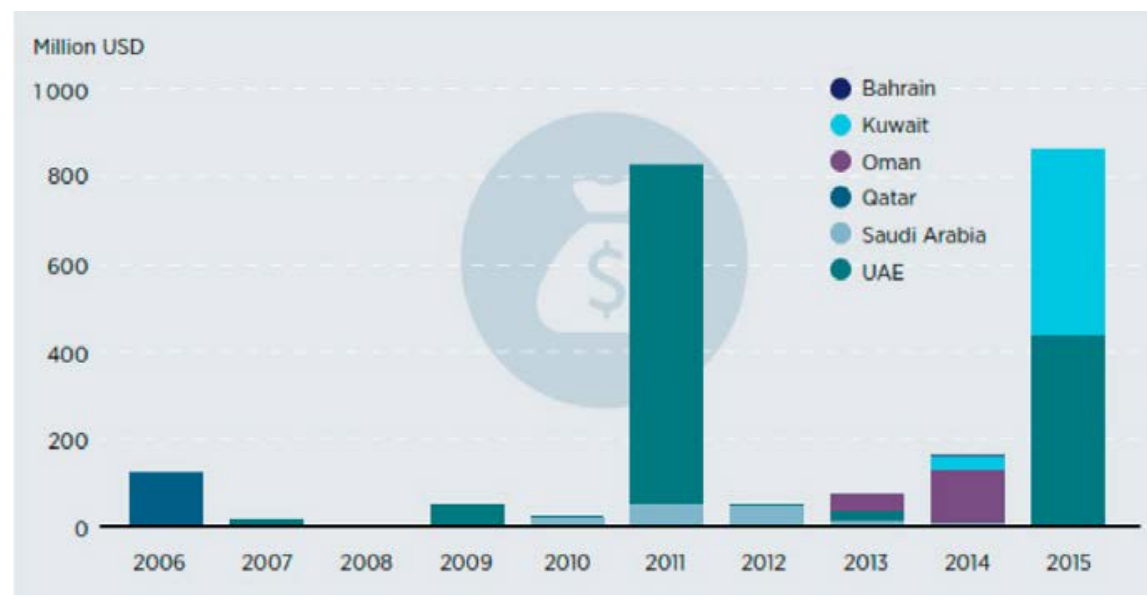

Figure 1: Investment in GCC renewable energy (Masud et al., 2018) 


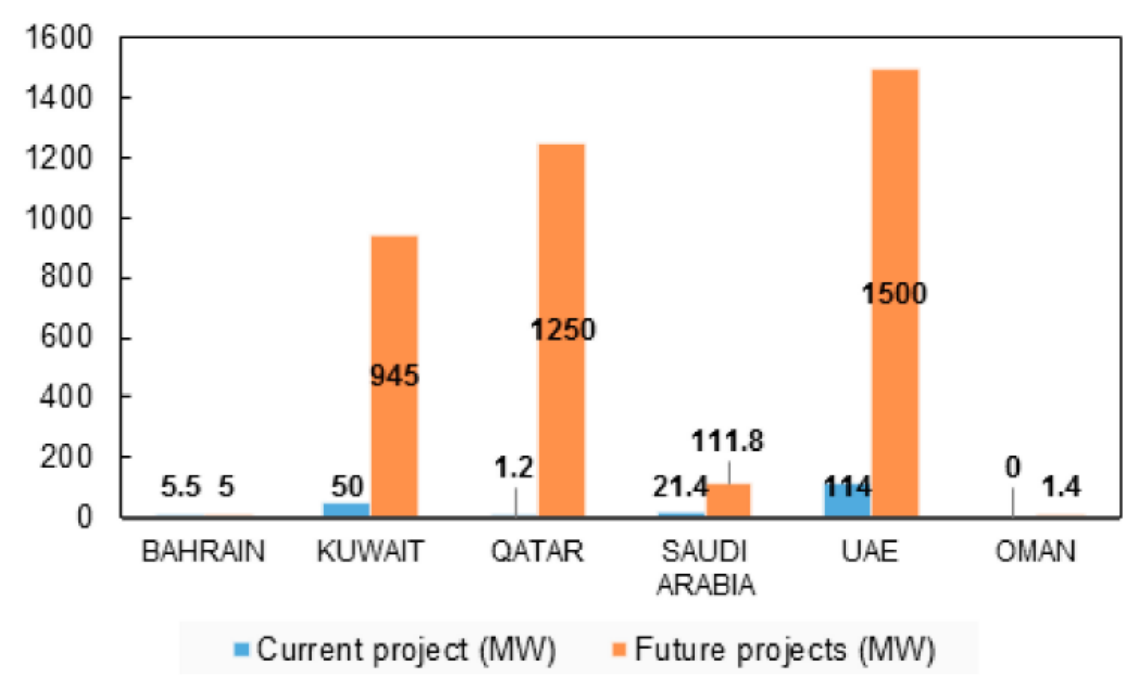

Figure 2: Current and future solar project in GCC (Masud et al., 2018)

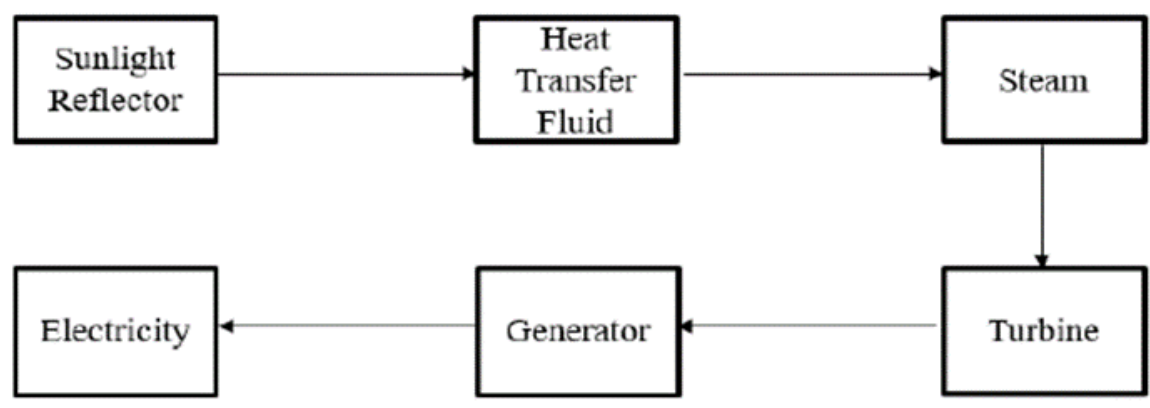

Figure 3: Solar thermal electricity generation

\subsection{HARVESTING SOLAR ENERGY}

The abundant of radiation in Kuwait country is the main reason why the harvesting of solar energy is considered as very promising. However, the implementation of solar photovoltaic system in Kuwait is different depending on the region it is installed. Rather than the knowledge of basic solar thermal electricity is needed, the differences of radiation in remote, urban and dessert area in Kuwait is also critical and is discussed in the next subtopic.

\subsubsection{Solar Thermal Electricity}

A solar thermal power system collects and concentrates sun energy to generate high temperature heat that is necessary to create electrical power. The system contains two main devices: reflectors and receivers. A reflector is basically utilized in capturing and focusing the sunlight into a given receiver. There is also a heat transfer fluid which is put under heat and then distributed in the receiver for the purpose of producing steam. The steam is later transformed into mechanical energy with the aid of turbines that power generators to create electricity as it is shown in Figure 3. It is important to note that there exists a tracking system that basically focuses the sun energy onto the receiver during the day, keeping in mind the changes in the position of the sun. A storage system known as thermal energy can also be utilized to store excess energy during hot days so as to be used during the night or cloudy days (Alhouli, 2017).

\subsubsection{Solar Energy Electricity in Remote Areas}

Access to energy offers great benefits to development through the provision of reliable and efficient lighting, heating, cooking, mechanical power, transport and telecommunication services. Additionally, access to power has proven economic welfare, as productivity increases with businesses, substituting manual work by automated processes and finally leading to a positive virtuous growth cycle (Halabi, Al-Qattan and Al-Qataibi, 2015).

One of these off-grid technologies is photovoltaic (PV) systems, which have been installed in many Developing Countries (DCs) aiming to provide people with electricity who would otherwise have to wait for years to get connected to the national power. It is well-known that solar PV produces electricity from sunlight through an electronic mechanism in a specific type of semiconductor material, commonly silicon. The sunrays induce free electrons from these materials to travel in an electrical circuit in order to power electrical systems or conveying the 
electricity to the grid. The PV panels can be installed on the ground, on rooftops or standing structures. The solar PV can contribute immensely to the socio-economic development of the GCC region. According to an International Renewable Energy Agency (IRENA) report, the GCC countries could gain numerous benefits from RE implementation.

\subsubsection{Photovoltaic Electrification in Urban Area of Kuwait}

It is a well-known fact that the GCC countries depend on oil as the major energy source, especially for power generation, which is non-renewable. The environmental impact from non-renewable energy (RE) sources such as gas and oil are enormous and can cause a major challenge for these countries. For example, an increase in high-carbon dioxide $\left(\mathrm{CO}_{2}\right)$ emissions that pollute the atmosphere and subsequently affect global warming (Mas'ud et al., 2018). Kuwait's annual solar radiation is predicted to be between 2100 and $2200 \mathrm{~kW} / \mathrm{m} 2$. The average daily sunshine hours/year for Kuwait range from 7 to 12. According to 2015 Kuwait Energy Policy, Laws and Regulations, the maximum solar radiation and the peak electricity demand in the country occurs at the same time of the year, making the solar PV the most useful RE source for the country. The primary energy source of Kuwait is 100\% from fossil fuel with oil supplying $52.8 \%$ and natural gas $47.2 \%$. The energy consumption in Kuwait varies according to the following vectors: $33 \%$ industrial, $19 \%$ transport, $23 \%$ residential and $25 \%$ non-energy uses and other consumption (Alazemi, 2017). Kuwait energy resources are managed by the Kuwait Petroleum Corporation and its subsidiaries are responsible for oil and gas production, exporting, importing and distribution. The acceptance of the Kyoto protocol by Kuwait in March 2005 allowed the country to rethink a plan for RE policy in agreement with the climate change mitigation objectives. Since then, there are Research and Development (R\&D) initiatives by the government aimed at promoting the application of solar PV and solar thermal systems in both public and private institutions. An environmental and social impact assessment carried out in 2012 to examine the solar PV in the North Africa and the Middle East showed that solar PV could be cost-competitive with oil-fired power generation (Al-Enezi et al., 2011; Bou_Rabee, 2015).

\subsubsection{Photovoltaic Electrification in Dessert Area of Kuwait}

Geography plays an integral role in determining what forms of renewable energy will be the most useful. Hydroelectric energy is the primary source of electricity for the countries of Canada and Brazil. Denmark, Germany, and the United States are increasing the number of wind turbines and offshore wind farms to meet the increasing energy demands. Other European nations are moving towards a renewable energy stance with increased photovoltaic and wind energy projects that will make up a large portion of their future infrastructure.

Austin et al, (2005) concluded that Australia, Japan, and third world African five countries use solar energy in isolated regions and cities to harness the sun's energy. Bollinger (2007) discussed that in the United States, the use of wind energy centres around the west coast and small to large wind farms scattered across the nation. The Southwest United States benefits from abundant sunlight and moderate weather during the winter. The Midwest is not known for employing renewable energy due to the lower cost of producing power from coal plants.

Also, the conditions of the land makes implementing hydroelectric dams difficult, the lack of mountain ranges and water sources reduce the average speed of the wind, and the high percentage of clouds in the winter hampers the use of solar panels (Feron, 2016). The implementation of solar energy has come from individual home owners that accept the cost involved and the number of consumers will continue to increase with a reduction in equipment cost and utility rate hikes. Photovoltaic energy has only been around a few decades, and came about through advancements in the space program. The performances of the individual cells of a solar panel are steadily improving with newer advancements with semiconductor material (Ramadhan and Naseeb, 2011; Ramadhan et al., 2013).

\subsection{SOLAR PHOTOVOLTAIC CELL}

A photovoltaic solar cell is generally a device used in the direct conversion of light energy into electricity with the aid of semi-conductors of electricity that unveil a photoelectric impact. A characteristic system of a photovoltaic utilizes solar panels, each made up of various solar cells that generate electricity. The installations of photovoltaic cells can be mounted on the rooftop, ground or the wall of buildings. The mounting can be done through fixation or simply through the employment of a solar tracker that follows the direction of the sun. No form of pollution is produced into the environment with the use of solar photovoltaic cells as there are no moving parts. Two most common type of PV cells are crystalline silicon (c-Si) PV cells and amorphous Silicon (a-Si) PV cells. The Elements and Components of PV Cells are briefly discussed here (Alhouli, 2017; Nuralam, et al., 2015). A sample of PV solar system is shown in Figure 4.

\subsubsection{The Inverter}

The electric current generated from the solar energy is basically direct current. Hence, for it to be used domestically in homes, it has to be converted into alternating current using an inverter. The inverter uses a series of solid-state switches to generate alternating current. A special type of inverter known as a grid-tie inverter is required if the electricity generated is to be utilized by the grid. Its main purpose is to match the electricity phase generated to the grid phase in order to avoid possible mismatches of the phases and hence, cancellation. In addition, the grid-tie inverter works as a safety measure. For instance, in the event there is a power blackout, it immediately switches off the supply line to the solar panel so as to avoid causing any harm to persons working on the power lines. 


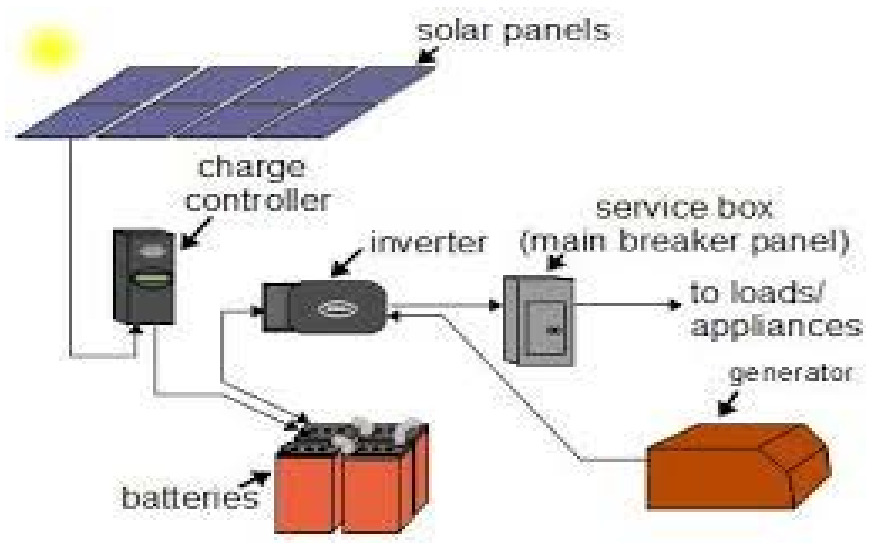

Figure 4: PV solar panel system to produce electricity (Rimstar, 2019)

\subsubsection{The Battery}

Some of the photovoltaic solar cells have an installed battery that is used to store the excess electric energy generated from the sun. This energy is put into use when the solar panels do not provide sufficient energy; for instance, during rainy or dark days. Hence, the battery is generally utilized off-grid. The connection of the battery system can be either serial or parallel. The flooded battery, which is a lead-acid battery system, is the most preferred in photovoltaic cells as they neither require distilled water nor electrolytes.

\subsubsection{The Distributor}

The distributor is used to distribute the AC power that has been generated by the inverter into the electric grid. At times, it can be used to distribute the electric energy generated not only to the grid but also the home that has been fitted with the solar system.

\subsubsection{PV Generator}

PV generator is used to convert the energy obtained from the sun into electrical energy. Its efficiency is currently estimated to be 15 percent. The device requires optimum conditions and environment so as to work efficiently and effectively.

\subsubsection{Charge Regulator}

The charge regulator offers protection to the battery system by monitoring the charging process to either slow down or halt the process to avoid overcharging. It increases the life of the batteries to effectively store the energy generated. However, if the solar panel does not use batteries, then there is no need for a battery regulator. The charge regulators are of different types and sizes depending on the photovoltaic system in use. It is important to note that the stability of the regulator should be reached at the maximum current. Since, in most countries of the world solar PV is the most commonly used, this paper will focus on the solar PV.

\section{RESEARCH METHODOLOGY}

The research initiative starts with relevant technical and government enforcement literature review in the field. Based on state of the arts literature review, problem statement, research objective, and scope are established. Research methodology is developed to carry out the research. Then experimental design and setup were prepared to conduct experiment and measurement of data. This research targeted to propose high efficiency off-grid photovoltaic system for Kuwait eco-tourism. The research started with the collection of weather data which includes the radiation, temperature and wind speed for a monthly basis. Next, the information regarding the electrical usage of Kuwait desert houses is needed. By having these weather data and electrical usage calculation, the simulation was done using PuSyst software. This software was used to design and analyse the photovoltaic system. The results of these analyses were the predicted performance of the annual solar energy production. Finally, the analysis will depict the suitability of the photovoltaic design for the houses in the desert.

\section{WEATHER DATA AND INFORMATION COLLECTION}

The first stage in this research was to select the available sites in Kuwait that is located in the desert which is suitable for eco-tourism activity. Kuwait consist of six governorates; Jahra, Al Asimah, Farwaniya, Hawalli, Mubarak al-Kabeer and Ahmadi. Among these governorates, Jahra which is at the western part of Kuwait have one of the highest amount of solar radiation. An area called Shagaya which located at $29.2^{\circ}$ latitude $(N)$ and $47.1^{\circ}$ longitude $€$ as shown in Figure 5 is selected as the location of interest due to the availability of the required data. In photovoltaic research, the most important data that is needed is the average monthly solar irradiation of the location. The irradiation data was collected from Kuwait Institute of Scientific Research (KISR). Other than irradiation data, the average duration 
of sunshine also is considered as important. This is important due to the photovoltaic performance is directly affected by the number of hours of sunshine. The data for the sunshine hours in Shagaya, as shown in Figure 5, is shown in Table 1. By having this information, it is still not sufficient in designing an off-grid solar photovoltaic system. Thus, the selection of photovoltaic type is discussed in the next subsection.

\subsection{PHOTOVOLTAIC TYPE SELECTION}

There are three different types of solar panels that is available in the market; monocrystalline silicon, thin film silicon and polycrystalline silicon solar panel. Thin film silicon is considered as very versatile due to its flexibility. However, this type of solar panel has large drawbacks which its efficiency percentage decreases over time, not durable and have toxicity concern. Therefore, only monocrystalline and polycrystalline silicon solar panels as shown in Figure 6 is available in the market of Kuwait. The comparison between both of the solar panels showed that monocrystalline is the best choice as it has higher quality number. Furthermore, this type of solar panel is very durable, have low maintenance, high heat resistance, high efficiency and environmentally friendly.

\subsection{THE SIMULATION OF THE DESIGNED OFF-GRID SOLAR PHOTOVOLTAIC SYSTEM}

The simulation of the electricity generated by the designed photovoltaic system was done using PVSyst software. This software capable to simulate grid-connected, stand-alone, pumping and DC-grid photovoltaic system. In this research, the selected mode is the stand-alone photovoltaic system. This software capable of performing a thorough system design using detailed hourly simulations under the 'Project Design' option as shown in Figure 7. Different simulation runs can be made with combinations of plane orientations, specific system components, number of PV array, inverter model, and battery pack. Detailed parameters can also be specified and analysed such as thermal behaviours, wiring, module quality, incidence angle losses, horizon, and partial shading.

Table 1: Monthly sunshine hours for Shagaya, Kuwait

\begin{tabular}{cc}
\hline Month & Sunlight (hours) \\
\hline January & 8 \\
February & 8.55 \\
March & 9 \\
April & 8 \\
May & 10 \\
June & 10 \\
July & 10 \\
August & 11 \\
September & 10 \\
October & 10 \\
November & 8 \\
December & 7 \\
Yearly average & 9.1 \\
\hline
\end{tabular}

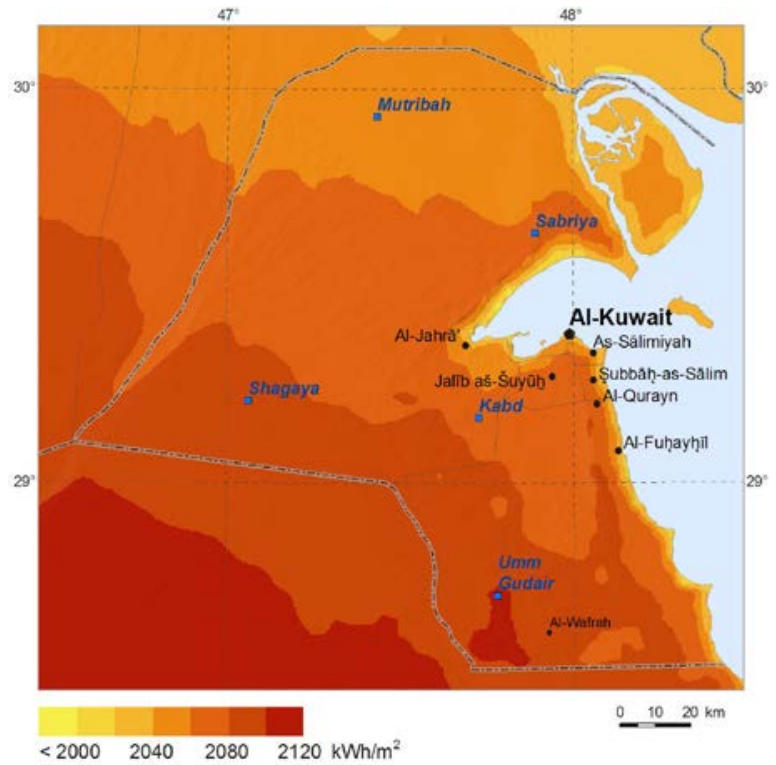

Figure 5: Shagaya on Kuwait solar map 


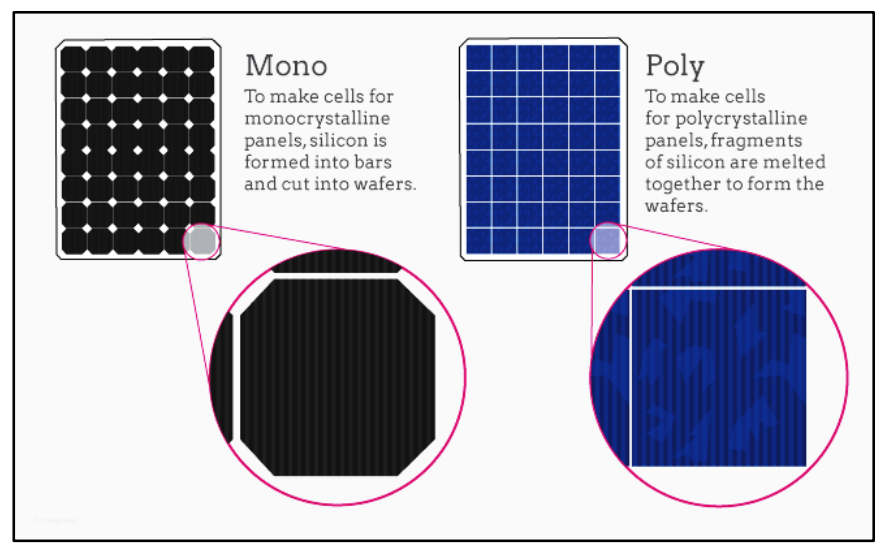

Figure 6: Monocrysttaline and polycrysttaline solar panel

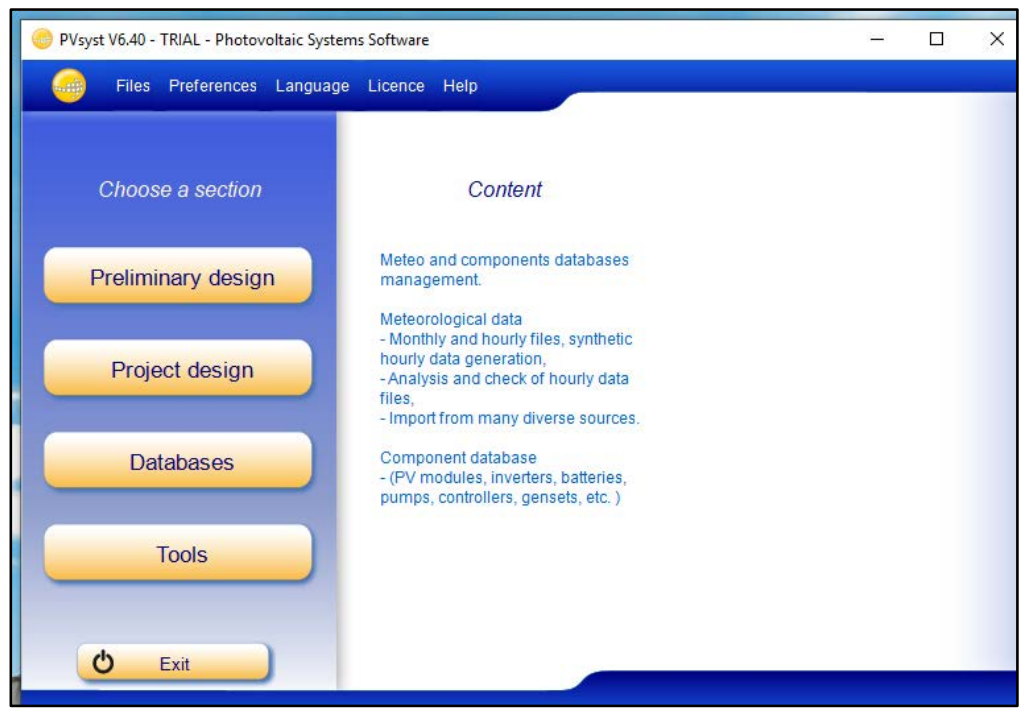

Figure 7: PVsyst V6.40 software interface

The reports generated by the simulations can be displayed in terms of monthly, daily or hourly values. The most important 'Loss Diagram' is particularly useful in identifying the weaknesses of the system design. Other than that, the detailed economic evaluations can be performed using real component prices, additional costs and investment conditions. Furthermore, the performance ratio graph, daily input/output diagram, and daily array output diagram is also available. In terms of useful tables, Pvsyst software provides balances and main results, incident energy tables, as well as losses in PV system. By incorporating all of these figures and tables, a comprehensive report of the designed PV system can be made without hassles.

\subsection{ELECTRICAL USAGE CALCULATION}

In order to conduct a simulation of an off-grid solar photovoltaic system, an example of calculation of electrical usage of typical house in Kuwait is needed. Table 2 shows an electrical usage of a typical house in Kuwait. From Table 4.1, it can be seen that the power consumption per month is $14,261.46 \mathrm{kWh}$. Thus, using Eqn 1 the daily consumption load of the house is $475.38 \mathrm{kWh} /$ day.

$$
\text { Daily load }=\frac{\text { monthly power consumption }}{30 \text { days }}
$$

As the proposed monocrystalline PV system requires batteries to store the collected electricity, a $20 \%$ factor of inefficiency is needed to compensate the power loss of the battery charge/discharge. Thus, Eqn 2 shows the daily power consumption needed by the house after considering the battery inefficiency. The calculated daily power consumption needed is $570.46 \mathrm{kWh} /$ day.

$$
\text { Daily power consumption }=\text { Daily load } \times 1.2
$$


Table 2: Electrical usage in Kuwait house

\begin{tabular}{cccccc}
\hline Application & Qty & $\begin{array}{c}\text { Power } \\
(\mathrm{kW})\end{array}$ & $\begin{array}{c}\text { Total power } \\
(\mathrm{kW})\end{array}$ & $\begin{array}{c}\text { Duration of } \\
\text { use } \\
(\mathrm{h} / \mathrm{day})\end{array}$ & $\begin{array}{c}\text { Power } \\
\text { consumption } \\
(\mathrm{kWh} / \mathrm{month})\end{array}$ \\
\hline Light (40 W) & 13 & 0.04 & 0.52 & 6 & 93.60 \\
Light (30 W) & 9 & 0.03 & 0.27 & 6 & 48.60 \\
TV & 5 & 0.20 & 1.00 & 2 & 60.00 \\
Washing machine & 3 & 0.42 & 1.26 & 1 & 37.80 \\
Microwave & 3 & 1.30 & 3.90 & 1 & 117.00 \\
Outdoor lights & 13 & 0.06 & 0.78 & 6 & 140.40 \\
Neon light & 12 & 0.02 & 0.24 & 6 & 43.20 \\
Indoor light & 62 & 0.06 & 3.72 & 2 & 223.20 \\
Wansa air condition unit (small) & 2 & 3.35 & 6.70 & 2 & 402.00 \\
Wansa air condition unit (large) & 1 & 13.00 & 13.00 & 2 & 780.00 \\
Central boiler & 1 & 9.00 & 9.00 & 3 & 810.00 \\
Water pump & 1 & 0.60 & 0.60 & 1 & 18.00 \\
A/C central unit 4 tons & 4 & 14.10 & 56.40 & 4 & $6,768.00$ \\
A/C central unit 5 tons & 2 & 17.60 & 35.20 & 4 & $4,224.00$ \\
Refrigerator & 4 & 1.41 & 5.64 & 3 & 507.60 \\
$\quad$ Total & & 61.19 & 138.23 & & $14,261.46$ \\
\hline
\end{tabular}

Next, the PV system voltage is rated at 12 volts, hence Eqn 3 was used to calculate the total current per hour needed in a day. The calculated value was $47538.2 \mathrm{~A}$-h/day.

$$
\text { Total current per hour }=\frac{\text { Daily power consumption }}{12 \mathrm{~V}}
$$

Based on Table 1, it can be noted that the sunshine in the targeted area, Shagaya is approximately 9.1 hours. This also means that the effective time of charging the PV is 9.1 hours per month throughout the year. Thus, the calculation of the power produced by the PV cells per hour is shown in Eqn 4.

$$
\text { Power produced by PV cells }=\frac{\text { Daily power consumption }}{\text { Average sunlight hour }}
$$

By using Eqn 4, it is found that the PV system arrays should produce $63.38 \mathrm{~kW}$ of electrical power per hour. However, a $10 \%$ power loss factor have to be added in order to compensate the inefficiency of the photovoltaic system. The calculation is shown in Eqn 5.

$$
\text { Hourly peak power needed }=\text { Power produced by PV cells } \times 1.1
$$

Using Eqn 5, the hourly power produced by the PV arrays is $69.723 \mathrm{~kW}$. Furthermore, based on the selection of monocrystalline PV type, it is known that a cell of monocrystalline PV type produces an average of $300 \mathrm{~W}$ of power. Thus, to calculate the amount of PV cells needed, Eqn 6 is used.

$$
\text { Number of PV cell needed }=\frac{\text { Hourly peak power needed }}{\text { Average production of power in one PV cell }}
$$

Finally, the calculated number of PV cells required for a house in Kuwait is approximately 233 cells with the total cost is $\$ 6,764.50$ USD. This is an example of calculation for the common houses in Kuwait. The suggested electrical usage is discussed in the next subsection.

\section{SUGGESTED ELECTRICAL USAGE FOR ECO-TOURISM}

By comparing the electrical usage in a regular residence, the usage for eco-tourism is considerably lesser due to less electrical applications. Therefore, a new electrical usage calculation is needed. The suggested electrical usage to be used in eco-tourism houses is shown in Table 3. It can be seen that the power consumption for the suggested electrical usage for eco-tourism houses per month is $274.32 \mathrm{kWh}$. Thus, using Eqn 1, the daily consumption load of the house is $9.144 \mathrm{kWh} /$ day. Adding a $20 \%$ factor of inefficiency due to monocrystalline photovoltaic type as stated in Eqn 2 the load for daily usage is $10.9728 \mathrm{kWh} /$ day. Next, the house for eco-tourism also uses the same system voltage at 12 volts, hence using Eqn 3 the total current per hour needed in a day is $0.9144 \mathrm{~A}-\mathrm{h} /$ day. 
Table 3: Suggested electrical usage in eco-tourism houses

\begin{tabular}{|c|c|c|c|c|c|c|}
\hline Application & Qty & $\begin{array}{l}\text { Power } \\
\text { (W) }\end{array}$ & $\begin{array}{l}\text { Total } \\
\text { power } \\
(W)\end{array}$ & $\begin{array}{c}\text { Duration of } \\
\text { use } \\
\text { (h/day) }\end{array}$ & $\begin{array}{c}\text { Power } \\
\text { consumption } \\
\text { (Wh/day) }\end{array}$ & $\begin{array}{c}\text { Power } \\
\text { consumption } \\
\text { (kWh/month) }\end{array}$ \\
\hline Lamps & 6 & 10 & 60 & 5 & 300 & 9.00 \\
\hline Television & 1 & 100 & 100 & 5 & 500 & 15.00 \\
\hline Domestic appliances & 1 & 500 & 500 & 4 & 2000 & 60.00 \\
\hline Refrigerator & 1 & 34 & 34 & 24 & 800 & 24.00 \\
\hline Ventilation & 1 & 100 & 100 & 24 & 2400 & 72.00 \\
\hline Air conditioning & 1 & 1000 & 1000 & 3 & 3000 & 90.00 \\
\hline Stand-by consumers & 1 & 6 & 6 & 24 & 144 & 4.32 \\
\hline Total & 12 & 1,750 & 1,800 & & 9,143 & 274.32 \\
\hline
\end{tabular}

\section{CONCLUSIONS AND RECOMMENDATIONS}

A solar photovoltaic system has been designed for dessert eco-tourism in Kuwait. Some insight on the Kuwait capabilities and future hopes for the design implementation is also shared for the recommendation purposes.

1. It was found that the solar renewable energy is feasible to be supplied towards the houses in the dessert for eco-tourism by stand-alone photovoltaic system. The suggested site for the photovoltaic research is Shagaya which is located at the western part of Kuwait.

2. A PV system was designed using a 60 cells monocrystalline type of PV module, 24 units of battery, and an MPPT converter controller. This design PV system is suitable to be used as the stand-alone system for the ecotourism houses.

\section{REFERENCES}

Absi Halabi, M., Al-Qattan, A., \& Al-Otaibi, A. (2015). Application of solar energy in the oil industry - Current status and future prospects. Renewable and Sustainable Energy Reviews, 43, 296-314.

Alazemi, F. K. (2017). Photovoltaic Energy in Kuwait : A Financial and Environmental Analysis. (Unpublished doctoral dissertation). University of Bath, United Kingdom.

Al-Enezi, F. Q., Sykulski, J. K., \& Ahmed, N. A. (2011). Visibility and potential of solar energy on horizontal surface at Kuwait area. Energy Procedia, 12, 862-872.

Alhouli, O. J. M. A. (2014) Using solar energy in Kuwait to generate electricity instead of natural gas. (Unpublished master's thesis). Kansas State University, United State.

Alrashidi, A. (2017) Investigating the Feasibility of Solar Photovoltaic Systems in Kuwait. (Unpublished doctoral dissertation). Loughborough University, United Kingdom.

Bou-Rabee, M. A., Sulaiman, S. A., Choe, G., Han, D., Saeed, T., \& Marafie, S. (2015). Characteristics of solar energy radiation on typical summer and winter days in Kuwait, 12 (December), 2944-2953.

Bryden, J., Riahi, L., \& Zissler, R. (2013). MENA Renewables Status Report, 21.

El-katiri, L. (2014). A Roadmap for Renewable Energy in the Middle East and North Africa. Oxford Institute for Energy Studies.

Feron, S. (2016). Sustainability of off-grid photovoltaic systems for rural electrification in developing countries: A review. Sustainability (Switzerland), 8 (12), 1-26.

IRENA. (2016). Renewable energy in the Arab Region: Overview of developments, (March). Retrieved from www.rcreee.org

Karim, R., \& Islam, M. R. (2016). A Comparative Study on Installation of Solar PV System at Garments Roof top Proceedings of 11th Global Engineering, Science and Technology Conference A Comparative Study on Installation of Solar PV System at Garments Roof top, (February).

Mahgoub, Y. (2014). Towards Sustainable Desert Eco-Tourism in Kuwait: Learning from the Regional Experience (January).

Mas'ud, A. A., Wirba, A. V., Alshammari, S. J., Muhammad-Sukki, F., Abdullahi, M. M., Albarracín, R., \& Hoq, M. Z. (2018). Solar energy potentials and benefits in the gulf cooperation council countries: A review of substantial issues. Energies, 11(2), 1-20.

Mezher, T., Dawelbait, G., \& Abbas, Z. (2011). Renewable Energy Policies Implementation Drivers and Barriers for Abu Dhabi. Proceedings of the World Renewable Energy Congress - Sweden, 8-13 May, 2011, Linköping, Sweden, $57,2501-2508$.

Mohammadi, Y., \& Ahmadi, K. (2019). Frequency domain analysis of regenerative chatter in machine tools with Linear Time Periodic dynamics. Mechanical Systems and Signal Processing, 120, 378-391.

Ramadhan, M., Hussain, A., \& Behbehani, D. (2012). The Prospect of Solar Energy in the Development of Power Stations in the State of Kuwait. Journal of Renewable Energy, 2013(ii), 1-6.

Ramadhan, M., \& Naseeb, A. (2011). The cost benefit analysis of implementing photovoltaic solar system in the state of Kuwait. Renewable Energy, 36(4), 1272-1276.

Rimstar (2019). Off-grid solar panel system, Rimstar.org (11 August 2019) https://rimstar.org/renewnrg/off grid solar power systems.htm 